\title{
INDEPENDENT PREPARATION OF INTERNS FOR THE LICENSE EXAM
}

\section{Natalia Khobotova ${ }^{1}$}

DOI: https://doi.org/10.30525/978-9934-26-076-6-4

In today's rapidly advancing medical technology with increased demands on the specialist the continuous process of improving the knowledge and skills of an intern, makes it extremely important to improve postgraduate education. The use of methods of activating the performance of interns creates modern person-centered approaches to training a young doctor. The decision-making on diagnostic and medical problems, situations, participation in training games provides high professional training. In the process of training all interns are forced to actively find, study and use educational and scientific information, which is more useful than traditional methods of training. The

\footnotetext{
${ }^{1}$ Dnipro State Medical University, Ukraine
} 
modern educational process actualizes the leadership qualities of young people, cultivating in them a taste for the new and progressive with the widespread use of the latest medical information technologies [1; 2]. Continuing education supports lifelong learning, creates conditions for selfeducation which contributes to personal progress. This provides a certain connection between the separate stages of the educational pathway. Currently, continuous self-education is becoming a necessary condition for the realization of individual preferences in the field of special medical knowledge. It is not only about professional development but also about qualitative individual progress of the intern which provides a high degree of subjective activity, free choice of decisions, the desire to improve general medical and ethical competence and spiritual culture, which becomes a way of selforganization [3].

Independent work of interns is one of the most important reserves for improving the efficiency of higher education and is distributed in the amount of $100 \%$ (for external study) to $30 \%$ (for full-time study). Acquisition of skills of independent planning and organization of own educational process provides smooth transition to continuous postgraduate education, first of all self-education. Independent training is a planned work of interns which is performed on the task and under the guidance of the teacher but without his direct participation. This type of training is designed not only to master related disciplines but also to develop skills of independent work in general in educational, scientific, professional activities; to acquire the ability to take responsibility, solve problems independently, find constructive solutions, a way out of a critical situation, etc. The teacher only organizes cognitive activity and the intern himself carries out cognition [4].

In higher educational institutions there are different types of individual independent work: preparation for lectures, practical classes, seminars, module tests, tests, exams; execution of abstracts, tasks, term papers and projects, preparation for the license exam. The ratio of time spent in the classroom to the time attempted for independent work worldwide is 1: 3.5. This is based on the great didactic potential of this type of educational activity.

Independent training contributes to deepening and expanding knowledge, the formation of interest in cognitive activity, mastering the techniques of the cognitive process, the development of personal abilities. The successful implementation of independent work is influenced by: motivation, clear statement of cognitive tasks, mastering algorithms, technique, methods of work, clear definition of report forms, scope of work, deadlines, consulting, clear evaluation criteria, reporting, etc., use of various forms of control 
(workshop, tests, testing) by the teacher. Independent work includes creative processes in the training of personality.

There are three levels of independent learning:

1) Reproductive - training independent work is performed on the model: solving problems, filling in tables, diagrams, etc. Cognitive activity is manifested in recognition, comprehension, memorizing. The purpose of this type of work is to consolidate knowledge, develop skills and abilities.

2) Reconstructive - in the course of reconstructive independent work the reconstruction of decisions, drawing up of the plan, writing theses, annotating is carried out. Summary writing can be performed at this level.

3) Creative (search) - independent work requires analysis of the problem situation, obtaining new information. The intern must independently choose the means and methods of solution (personally simulate a problematic medical situation, create a valid test task, etc.) [5].

Motivation of the academic assignment is the first condition for successful performance of independent work, characterized by a set of motivations (motives) that cause the activity of the individual; system of factors that determine human behavior. Motivation for the subject must be a continuous process. Motive, in contrast to motivation, is a personal property, motivation to act, initiation of actions and deeds. Motives are formed from human needs, are conscious and unconscious. The main categories of motives: the motive of success, the motive of avoiding failure, the motive of power, the motive of affiliation (desire to communicate) [6]. It is optimal to base motivation on cognitive interest. The stronger the cognitive motivation, the greater the ability to solve complex problems. If the intern enters upon a lesson with a compound motive, then no special work is required at this stage. Otherwise, it is necessary to use external or internal motivation to ensure the inclusion of a young colleague in joint activities with the teacher.

Needs and motives can urge the subject to action not only to master the object but also to avoid it (when the object has a negative valence associated with the threats resulting from (the ability to experience unpleasant feelings, to lower the social status, etc.) Protective mechanisms of this nature is a psychoanalytic category that combines a set of unconscious techniques by which a person protects himself from psychological trauma. time limit, etc.), uses to the full strong points of the personality due to the independent choice of time and methods of work, etc.

The main ways to increase the activity of the subject and the effectiveness of the entire educational process are: strengthening the learning motivation of the intern through internal and external motives (stimulating motives); creating conditions for the formation of new predominant forms of 
motivation: the desire for self-actualization, self-expression and selfknowledge in the learning process.

Self-education is a conscious activity of a person aimed at selfdevelopment and the formation of the own basic culture. Self-education should strengthen and develop the ability to voluntarily fulfill obligations (both personal and based on the requirements of the team), to form moral and volitional qualities, characteristics of behavior.

The final condition for the success of self-training is creativity - an activity that gives new material and spiritual values. Creativity reveals a person's need for self-expression, self-actualization and realization of their creative potential.

\section{References:}

1. Yekhalov V.V., Sliva V.I., Stanin D.M., Lyaschenko O.V., Kligunenko Ye.N. (2011) Printsipy podgotovki vrachey-internov raznykh spetsial'nostey po tsiklu «Neotlozhnye sostoyaniya» [Principles of training of interns in different specialties on «Emergencies» discipline]. Emergency Medicine, no. 4(35), pp. 126-128.

2. Vershlovskiy S.G. (2010) Sistema obrazovaniya vzroslykh kak ob»ekt prognozirovaniya [The system of adult education as an object of forecasting]. Man and Education, no. 1(22), pp. 16-21.

3. Zinkevich E.R. (2012) Razvitie pedagogicheskogo myshleniya vrachey prepodavateley meditsinskikh vuzov $\mathrm{v}$ usloviyakh nepreryvnogo obrazovaniya [The development of pedagogical thinking of doctors - medical university teachers in the conditions of continuing education]. Man and Education, no. 1(30), pp. 103-107.

4. Shurupova R.V., Maksimov K.V. (2008) Razrabotka sistemy innovatsionnogo potentsiala obuchayushchikhsya $\mathrm{s}$ ispol'zovaniem aktivnykh form obucheniya [Development of a system of innovative potential of students with the use of active forms of learning]. Proceedings of the Sistema menedzhmenta kachestva $i$ optimizatsiya obrazovatel'nogo protsessa: materialy uchebno-metodicheskoy konferentsii sotrudnikov Akademii, posvyashchennoy 250-letiyu MMA im. I.M. Sechenova (Russia, Moscow, October 14, 2008) (eds. Pal'tsev M.A., Litvitskiy P.F.), Moscow: Izdatel'skiy dom «Russkiy vrach», pp. 375-377.

5. Gaiduk O.I., Bashkirova N.S., Yekhalov V.V. (2015) Optymizatsiia samostiinoi pidhotovky likariv-interniv za fakhom «Zahalna praktyka - simeina medytsyna» [Optimization of independent training of interns in the specialty «General practice family medicine»]. Proceedings of the Realizatsiia zakonu Ukrainy «Pro vyshchu osvitu» u vyshchii medychnii ta farmatsevtychnii osviti Ukrainy (z distantsiinym pidiednanniam VM(F)NZ Ukrainy za dopomohoiu videokonferentszviazku) (Ukraine, Ternopil, May 21-22, 2015), Ternopil: TDMU, pp. 427-428.

6. Lukovtseva A.K. (2008) Psikhologiya i pedagogika : Kurs lektsiy [Psychology and pedagogy. Course of lectures]. Moscow: Mir i Obrazovanie. (in Russian) 